\title{
Weathering the storm: contesting disaster governance after Hurricane Matthew in Haiti
}

Samantha Melis ${ }^{1 *}$ and Mikel Jean ${ }^{2}$

\begin{abstract}
As a disaster unfolds, survivors' experiences, actions and motives often become overshadowed by the humanitarian response. This is especially the case in contexts where the national state and international organizations are seen to perpetuate (colonial) power structures. This article is based on 4 months of fieldwork in Haiti, where the authors conducted interviews and focus group discussions with people affected by Hurricane Matthew and with a variety of state officials and humanitarian response actors in Port-au-Prince, Jérémie, Les Cayes and Dame Marie. This study aimed to understand the role and power of societal actors in a context where there is a strong disarticulation between the state and society. The findings show that state-society tensions have been intensified in the response, leading to the politicization of aid and limiting the inclusion of affected communities in disaster governance. In this context, society-based actors negotiate the conditions of aid through resistance and solidarity, with strategies ranging from public protests to everyday resistance and from social networks to alternative aid structures. The article argues that disarticulation between society and the state needs to be addressed to make a more locally led response possible.
\end{abstract}

Keywords: Disaster governance, Disaster response, State-society relations, Humanitarian aid, Localization, Postcolonial, Post-conflict

\section{Introduction}

'The eye of the cyclone stayed here for one hour. We thought everything would be destroyed. There was much damage. The city became like a wilderness. [...] I remember the calm, so I went to see what happened, and then the wind and rain came again. The eye of the cyclone is like that. No unidirectional wind, but it came from all directions. Even the water came far from the sea. You were able to taste the saltwater on your lips.' (Mayor of Dame Marie, 5 March 2019)

In the eye of the storm, the response to disasters can be likened to the chaotic winds of the storm, stirring up the troubled waters underneath. Previous work in

\footnotetext{
* Correspondence: melis@iss.nl

${ }^{1}$ International Institute of Social Studies, Erasmus University Rotterdam,

Kortenaerkade 12, 2546 BK The Hague, The Netherlands

Full list of author information is available at the end of the article
}

humanitarian studies has shown that societal actors seeking a larger role in the governance of disaster response continue to struggle. This is often attributed to their limited access to humanitarian resources and to the concentration of power in international structures (Barnett 2011; Donini 2012; Geoffroy and Grünewald 2017; Fast 2017). Societal actors' motives are quickly questioned by aid actors, as they are often seen as passive 'recipients' who try to increase their access to the incoming aid. The mistrust and control between aid and societal actors seem to conflict with international disaster governance policies seeking solutions with (or within) communities through the focus on the localization of humanitarian aid (The Grand Bargain 2016), disaster risk reduction (UNISDR 2015) and the strengthening of resilience (Tiernan et al. 2019).

\section{Springer Open}

(- The Author(s). 2021 Open Access This article is licensed under a Creative Commons Attribution 4.0 International License, which permits use, sharing, adaptation, distribution and reproduction in any medium or format, as long as you give appropriate credit to the original author(s) and the source, provide a link to the Creative Commons licence, and indicate if changes were made. The images or other third party material in this article are included in the article's Creative Commons licence, unless indicated otherwise in a credit line to the material. If material is not included in the article's Creative Commons licence and your intended use is not permitted by statutory regulation or exceeds the permitted use, you will need to obtain permission directly from the copyright holder. To view a copy of this licence, visit http://creativecommons.org/licenses/by/4.0/. 
However, it is not only the power divide between the international humanitarian system and the affected communities that determine the parameters of the societal space in the response. The contrast between international policies and the experienced reality of people affected by disasters highlights the importance of understanding the different structures that shape the power relations limiting society's role in disaster response. Scholars have critically examined the international aid system and aid-society relations (Hilhorst 2013, 2016; Barnett 2013; Cunningham 2018), explored community perspectives and understandings of disasters (Bakewell 2000; Bankoff 2003; Krüger et al. 2015) and engaged with state-society disarticulation in the wake of disaster (Pelling and Dill 2010; Venugopal and Yasir 2017; Siddiqi and Canuday 2018; Melis and Hilhorst 2020). Nevertheless, the impact of state-society relations on how the response to disasters is governed has received less attention, especially seen from a bottom-up, societal perspective. Lack of knowledge on this topic is problematic because it is through society-state relations that the role of and space for societal actors is shaped before and after disasters, and this understanding would seem essential to the humanitarian localization agenda.

After a disaster, people's relationships with both state and aid actors are impacted by perceptions of the response and of people's power to negotiate the conditions of aid. These relationships have sometimes reflected an acceptance, or resilience, of the existing power structures (Siddiqi and Canuday 2018). At other times, major rifts have been observed, with powerful social movements arising or gaining momentum after disasters. In these cases, the disaster serves as a 'tipping point' for socio-political change through the breakdown of the social contract between the state and society (Pelling and Dill 2010). However, in practice, the effect of disasters on society-state relations might not always be so extreme and can be situated in the middle. Haiti has experienced multiple crises and protests, including the recent anti-government blockades in 2018-2019, but the postMatthew period did not directly create a 'tipping point'. Rather, the disaster can be said to have created ripples. The period was, as we argue, 'exceptionally normal' in the sense that something as seemingly exceptional as a disaster was shaped by the normal power relationships between different actors.

This study aimed to understand the 'in-between', everyday politics of society-state-aid relations, which are not broken or entirely contested, but rather expressed in purposeful societal (in)action towards state and aid structures after a disaster, exposing ripples in troubled waters. Through exploring the everyday realities and motives of people affected by disaster, this research shows the importance of asking how societal actors experienced structural society-state relations in response to Hurricane Matthew and how they wielded and negotiated their power to challenge the system and reshape aid conditions. The findings show that the tensions between society and the state have had a negative impact on aid-society relations, especially on the space of societal actors to co-shape the conditions of aid.

This article starts with a theoretical discussion to contextualize society-state relations in disaster response governance and how these are seen more generally in Haiti. Based on a thematic analysis, the findings are discussed in three sections. First, it shows how societal actors have experienced the state- and aid-led response to Hurricane Matthew, wherein the politization of aid resulted in a limited role for societal actors. Second, it analyses how societal actors resisted the power of the state and aid actors to decide on the conditions of the response. Third, it illustrates the importance of solidarity initiatives that societal actors undertook to shape an alternative response.

The findings have direct implications for multi-level humanitarian responses, especially in a context with a strong society-state disarticulation that is expressed in a mistrust of local and national state authorities. The limited role for societal actors in the response is a result of tensions in the everyday power relations between different actors, which have not been adequately redressed. Therefore, the space to challenge this power is limited and negotiations of societal actors to shape the conditions of aid delivery finds expression in everyday resistance and solidarity practices, instead of large social movements. The findings contribute to understanding disaster response governance from a social lens in settings described as 'post-conflict', or experiencing political crises without high-intensity conflict, where humanitarian 'emergencies' often stem from structural vulnerabilities.

\section{Society-state relations in disaster response governance}

Societal power within society-state relations

People living in the affected areas are the first and last responders after a disaster. These people are both affected by the disaster's impact and working to reduce this impact-saving lives, providing shelter, sharing food and clearing roads. Societal actors do not operate in a vacuum; they are connected to other actors and structures operating in this shared space. 'Society' is a relational term, with people who are inherently interconnected acting both as individuals and as groups or organizations.

Society can be described as a web, with multiple power centres or fragmented control centres that are connected (Migdal 2001). This conception reflects an 
understanding of society as comprising semi-structured relations between individuals, groups and institutions, as opposed to an aggregation of disconnected parts. The idea also shows that there are power centres connecting different parts of society and that multiple authorities exert control, either through society's governance structures (state actors) or through a more civil societal role (societal actors).

State-society relations concern the interactions and power relations between state and societal actors. These relations are generally discussed in the form of a 'social contract', where explicit or implicit rules and agreements determine people's behaviour. After a disaster, state-society relations are often (con)tested, but there is disagreement as to how the social contract is impacted. Pelling and Dill (2010) have argued that a social contract can break down after a disaster, especially in conflictaffected contexts. In contrast, Siddiqi and Canuday (2018) have shown that the social contract is quite resilient, with state-society relations being reproduced in the wake of a disaster and determining much of how state actors respond. Although it is unclear what conditions lead to a break-down or why others are more resilient, in both of these perspectives, it is clear that state-society relations affect the response to disasters and determine the space for societal actors to act within it. State-society relations are continuously (re)negotiated after a disaster.

Instead of looking at state-society relations, which take the state's responsibilities and functions as a starting point for societal action, this article examines the inverse, society-state relations, approaching society's relationship with the state through a social lens. Taking this society-state-aid relations approach, with its focus on societal actors, we analyse the negotiations between these actors in the wake of a disaster, when people navigate different power centres and negotiate the outcomes of aid (Hilhorst and Jansen 2010). In order to do so, we need to understand different forms of power that societal actors wield, especially in relation to the state, and how this power is shaped.

In a post-disaster response, (re)negotiated power relations affect the role and legitimacy of societal actors serving as response actors in the disaster governance framework (Tierney 2012). Here, the inter-relational aspect of power is crucial and often finds expression in practices and processes of resistance and acceptance (Foucault 1984; Giddens 1984; Hayward 2000; Lukes 2004). Resistance takes many forms, has multiple objectives and includes a variety of actors. In the public arena, it often takes the form of organized or spontaneous protests, and it can be a one-time performance or a continuous social movement (Gurr 1970; McAdam 1982; Tarrow 1998). In the private arena, individuals or groups of individuals may engage in resistance without overt displays. Such forms of 'everyday resistance' and 'infrapolitics' (Scott 1976), which are relatively difficult to observe and understand because they become ingrained in the social consciousness and habits, are also seen in disaster governance (Wisner 2016).

Disaster governance is one site where power relations are navigated. It poses a particular challenge when societal actors' relationships with state and aid actors are tense. Although Haiti has not been 'at war', as Donais and Knorr (2013, p. 57) note, 'the Haitian conflict may be considered an ongoing crisis in state-society relations'. Focusing on the relations between societal actors and the state is therefore particularly important in the Haitian context. Disaster governance is shaped by the socio-political and economic contexts and discourses that constitute power structures-the disarticulation between societal and state actors, how society's power is framed and which alternative structures are formed.

Society-state-aid relations are rooted in historical pathways that continue to shape power structures. When these types of drivers of vulnerability are not acknowledged, they can even lead to disaster risk creation (Lewis 2012; Wisner 2016). A growing body of literature in development studies situates these power structures in the discourses and practices of colonialism, neocolonialism and neoliberalism. Although these concepts are not interchangeable, they are characterized by similar features: namely, dominant power and a dichotomy between the elite and the rest of society. Colonialism has been argued to be a fundamental problem (Césaire 2000), and decolonization, including changing power structures, remains an ongoing process (Mignolo and Escobar 2010; Maldonado-Torres and Cavooris 2017; Mignolo and Walsh 2018). In the tradition of decolonial theory, Quijano (2000) coined the phrase 'the coloniality of power' to describe a certain type of structural power. Coloniality is, in essence, the internalization and reproduction of colonial power relations after colonialism that permeate all aspects of life (Quijano 2000). Viewing humanitarianism through this lens can contribute to a better understanding of the position of societal actors vis-à-vis state and aid actors in disaster response.

\section{Disaster governance in Haiti: politics of coloniality and crisis}

The discourse and internalization of colonialism have shaped the literature on Haiti. In the scholarly research, Haiti has become a prime example of a country whose colonial past continues to shape its present (Lundahl 1989; Dubois 2013). Scholars working on Haiti have argued that its colonial history has contributed to vulnerability and tense society-state relations in different ways. As Schuller (2016, p. 23) has noted, Haiti's 
vulnerability is rooted in 'a long-term process of exploitation by foreign powers', both during and after the colonial period. The indigenous population was decimated by the end of the colonial period and replaced through the slave trade, which resulted in a loss of indigenous knowledge on how to manage disasters. The situation in Haiti differs from some other post-colonial contexts, where the colonial regime integrated some form of disaster risk reduction, as Artur (2011) demonstrated in the case of Mozambique, for example.

It is important to interpret the Haitian people's relationship with their state through this historical perspective. In the Haitian colony, governance was centralized and operated in a bureaucratic, authoritarian manner and the plantation system created racialized political structures. This system, which was largely based on class divides and a form of the state that people would 'use' rather than serve, became the 'new normal' from which revolutionaries built after the colonial period (Casimir and Claypool 2012). In this way, colonial structures were carried over into post-colonial social organization and continued to define much of the society-state tension, with societal actors experiencing the state's 'politique $d u$ ventre ${ }^{1}$ (Fatton 2002) in everyday realities.

Whereas the Haitian state is centralized and elitist from the perspective of the people, in relation to international actors, the state becomes subordinate, shifting from the position of the ruler to that of the ruled (Fanon 2002). The state is accountable to the international community but not to its own people. As Fatton (2011, p. 171) argued, decades of policies have 'emasculated the state'. Several root causes set in motion the perpetuation of risk drivers and power dynamics in society-state-aid relations in Haiti and strengthened society's perception of the state as dependent on foreign actors.

The dependency of both the state and societal actors in Haiti on external actors has often worsened after disasters. Disasters have increased imports and destroyed businesses through the free or subsidized distribution of goods (Jean-Louis and Klamer 2016). The increased dependency strongly affected how aid actors are viewed in Haiti. In times when the humanitarian presence is felt particularly strongly, INGOs are seen as 'thieves', stealing the resources that are supposed to be for the Haitian people (Schuller 2016, p. 154).

Some scholars have criticized the decolonial perspective (Vickers 2019). Indeed, the dependence observed in Haiti cannot be blamed solely on external actors; corrupt regimes have often facilitated the imposition of

\footnotetext{
${ }^{1}$ An expression that refers to a post-colonial governance where the state is seen as elitist and 'consuming' resources at the expense of the people. It encompasses a type of patrimonialism that is characterized by corruption.
}

neoliberal policies, and class struggles have further marginalized the rural population (Casimir et al. 2011). Nevertheless, it is useful to critically interrogate how historically influenced power structures continue to take shape through internalized discourses and interactions (Berger et al. 2002).

From an international perspective, the narrative on Haiti has been dominated by the ideas of crisis and exception (Jenson 2011). According to Svistova and Pyles (2018), dominant discourses have constructed an image of the Haitian people as violent 'savages' involved in looting and stealing (Solnit 2010; Mason 2011). These images have perpetuated representations held since the nineteenth century (Ulysse et al. 2015). As they have become part of aid-society relations, they expanded the rift between the elites and other people in society, as well as resulting in societal actors experiencing these social constructions as structural violence. The crisis narrative around disasters is not unique to Haiti; discourses of crisis and exceptionality are also found in traditional humanitarianism worldwide (see Hilhorst 2018).

Instead of focusing on how aid and state actors dominated the disaster response, in this article, we aim to show how Haitian actors experienced and challenged the disaster governance of the state and aid actors, coshaping the response to Hurricane Matthew.

\section{Navigating troubled waters after Hurricane Matthew}

On 4 October 2016, Hurricane Matthew made landfall in southwest Haiti, leaving a trail of destruction in its path. Although the hurricane affected the entire country, the Sud, Grand'Anse and Nippes departments ${ }^{2}$ bore the brunt of the disaster. The hurricane affected over 2.1 million people, 1.4 million of whom were in need of humanitarian assistance (OCHA 2016). Over 500 people died in the hurricane and its aftermath, and more than half a million were forced to seek refuge with friends, families, neighbours or in shelters.

Before Hurricane Matthew reached the Caribbean coast, preparedness and response mechanisms were set in motion. The National Emergency Operations Centre (Centre des Operations d'Urgence National) ${ }^{3}$ was activated on October 1st, and the interim president of Haiti issued a warning to prepare for the hurricane on October 2nd. Civil Protection Directorate (Direction de la Protection Civile; DPC) members and volunteers, including the Conseils d'Administration de Section Communale (CASEC $)^{4}$, were responsible for informing

\footnotetext{
${ }^{2}$ Haiti is divided into 10 departments, 41 arrondissements, 146 communes, 571 sections communales

${ }^{3}$ On the level of the commune, there was a Centre des Operations d'Urgence Communale to coordinate disaster response effort

${ }^{4}$ The CASEC is local governance body for the communal sections (sections communales).
} 
communities of the approaching hurricane. Many people heard about the impending hurricane from DPC volunteers with megaphones on the street, radio announcements, social media and messages from family members or friends. However, due to society-state mistrust, not everyone believed the state's information, and in remote areas not everyone was reached.

Keeping the lessons of the 2010 earthquake in mind, and considering the lesser scale of the destruction, state and aid actors involved in the Hurricane Matthew response took a different approach to the disaster and to each other. Whereas the response to the 2010 earthquake was characterized by the state and societal actors being overpowered by the international humanitarian system (Rencoret et al. 2010; Bhattacharjee and Lossio 2011; Farmer 2012), and the response becoming a prime example of 'disaster capitalism' (Klein 2008; Dupuy 2010), the response to Hurricane Matthew was largely led by the Haitian state. Further, an emergency was not declared, which prevented the activation of the United Nations clusters and thus international control over the response.

With the response to Hurricane Matthew also being characterized by donor fatigue that affected the available resources (Grünewald and Schenkenberg 2017), state actors played a dominant role. Society-state disarticulation intensified, as seen in the divide between the political elite and others, for example. As Hsu and Schuller (2019) have argued, the limited response to Hurricane Matthew was largely caused by the 'Republic of Port-auPrince' neglecting the rural moun andeyo (a common phrase to denote 'people outside' or the rural communities). The findings of this article aim to answer the questions that remain: how was this divide practically experienced in the affected areas and how did societal actors challenge it?

\section{Methods}

The authors conducted the research for this article over the course of four months from January to April 2019. Author 1 was based in Port-au-Prince to conduct interviews with response actors on the national level. The selection of districts and communities to be included in the research was guided by meetings and discussions with response actors. Authors 1 and 2 selected the focus areas of Jérémie, Dame Marie and Les Cayes to research the societal response in areas that were strongly affected by the hurricane and that attracted considerable international attention. We interviewed 20 society-based actors (such as representatives of community-based cooperatives and associations, religious leaders and private sector actors), 15 local state actors and 23 aid-based actors (9 NGOs, 7 INGOs and 7 international organizations). We also conducted three group interviews and three focus group discussions with each fifteen community members, some of whom were members of community-based associations. The interviews were interpreted from Haitian Creole to English to allow both researchers to engage with the participants. Furthermore, periods of participant observation allowed the authors to become aware of the less overt dynamics between the research participants.

The Western background of author 1 may have negatively impacted the group discussions and the interpretation of the contextual nuances, because of how external researchers are sometimes perceived. However, this risk was mitigated by the Haitian background of author 2, who also had professional experience conducting and organizing focus group discussions. At times during the January to April 2019 research period, nation-wide protests inhibited the authors' movements. However, this situation also provided an opportunity, as it opened a space to discuss the contextual and structural issues more broadly in everyday encounters.

After a literature review and data collection, the interviews were transcribed, stored in NVivo and coded by author 1. Content analysis was conducted using Nvivo software. Interview data was coded to identify emerging categories and themes, from line-by-line coding to more thematic coding (Glaser and Strauss 1967; Braun and Clarke 2006). The main themes revolved around tensions within actor relations (especially society-state and society-aid), challenges experienced by societal actors in the response (such as power relations, aid politicization and limitations to societal space in the response) and social practices to shape aid conditions (different types of social negotiations, societal resistance and solidarity). The research took an inductive approach to the data collection and analysis, without pre-defined frames, to allow for the perspective of the affected population to be most central.

\section{In the aftermath of disaster}

Society meets state: societal space limited by politics and power

Most Haitians encounter the state in the form of the CASEC, mayors and the commune branches of different ministries. When Hurricane Matthew struck, newly elected mayors had recently taken office, CASEC elections would follow in a few months and the presidential election period was in full swing. The research found that tensions and mistrust between society and the state negatively impacted the space for societal actors in the response.

The mayor's office in each commune became a centralized point for distributing aid items to the communal sections. In this setting, the state's influence was strong but also contested by societal actors, with CASEC 
members forming a bridge between the state and societal actors. Still, the CASEC, and other community leaders, were not always supportive of the state's centralized manner of aid distributions. When we spoke with a CASEC representative, he asserted that a mayor's office did not share aid items equally over the communal sections and that most items stayed in the communal centre 'because when you are not on the mayor's team, he will not call' (GOV15 5 , 7 March 2019). This view was echoed by other community leaders in our research, such as a voodoo priest who felt he was left out of the coordination meetings so that aid items could be distributed to the more 'fortunate ones and the unfortunate find nothing' (SOC4, 8 March 2019).

Most communal sections members who participated in the focus groups near Dame Marie and Les Cayes strongly believed that the mayors did not distribute aid equally but instead gave priority to their partisans from the commune, neglecting residents of smaller villages. One example mentioned by the participants concerned a mayor who distributed cards that could be redeemed for tarps and food but then took the cards back to distribute to his friends and supporters. Another example concerned a mayor not openly selecting names for distributions, resulting in a lack of transparency regarding who would receive aid (FG2, 8 March 2019). Some community members who explicitly mentioned having a close relationship with the mayor received more help through this office, thus confirming the popular opinion regarding partisan practices (SOC21, 22 April 2019). This centralized sphere of influence on the sub-national level caused remote communities to receive less support, and aid actors who included the mayor's office in their distributions were consequently viewed relatively negatively.

At the community level, how communal leaders acted in the response as intermediaries between society and the state affected their legitimacy and the social cohesion in the community. A CASEC member elected postMatthew, who was from a different political party from that of the mayor, had been very active in the response, whereas a former CASEC member from the mayor's party was accused of partisanism during the response (GOV14, 8 March 2019). This was much like the case of another CASEC leader, who was not re-elected after being found to have withheld aid items, as recounted in an interview with a Haitian NGO representative (NGO2, 4 April 2019). Publicly challenging partisan practices could strengthen the legitimacy of individual leaders, as we observed in the case of a popular CASEC member. This

\footnotetext{
${ }^{5}$ Interview codes; SOC: societal actor, GOV: state actor, NGO: nongovernmental organization, INGO: international non-governmental organization, IO: international organization. Focus group discussions are coded as FGD and Group Interviews as GI.
}

man had a critical attitude towards the urban power centres, and his attempts to bypass state structures and contact aid actors directly were met with enthusiasm in the community (GOV15, 7 March 2019). From the stories of CASEC members and their communities, we observed that more people would suspect a CASEC member of bias when this person was seen as being closer to the power centres and farther removed from their societal foundation, underlining the mistrust between society and the state. As mentioned above, the national election period coincided with Hurricane Matthew, and CASEC elections also followed within a few months. In this context, people viewed the politicization of aid as infiltrating all levels of governance.

The response further exposed the tensions between societal actors and the central state. In the interviews, many community members recounted that national-level political candidates used aid distributions for campaign purposes and that they failed to follow through on their promises. Research participants mentioned that the presidential party distributed water packs and aid items bearing the party's logo. Jovenel Moise, then a presidential candidate, flew to the affected area to show his support. A church leader in Les Cayes eloquently conveyed a sentiment that was often expressed in the research: 'Candidates have three horses: First, they will promise to do something for you. Second, they will give some of you something. Third, they don't care about you' (SOC13, 23 April 2019). Many interviewees recounted losing confidence in politicians. Rumours accusing politicians, mayors, senators and deputies of diverting aid were abundant. One CASEC leader used powerful words to express the sentiment of how society experiences the 'politique du ventre' (Fatton 2011) of the Haitian state: 'They use the misery of people for politics' (GOV8, 22 April 2019). Another CASEC leader offered advice: 'The government should take the situation to its foundation. If the government keeps doing things on the top, it won't have any improvement because the foundation is the most important part of the house' (GOV15, 7 March 2019). Community members felt that aid was stuck in the political centres and that it needed to be transferred to all people, also in the more rural areas, to strengthen the foundation.

Although most community members participating in the research did not see the state as acting in their interests or feel they had the power to negotiate with the state, they also did not see much room for negotiation with aid actors. Many aid distributions were experienced as chaotic and badly organized. Furthermore, not all aid was considered appropriate for the needs of the affected people. As one cooperative member pointedly explained, 
They came to improve the life of people, but they make these people poorer. They came with something, and they went back with the thing again. They came with employees, and those employees found the best jobs with high salaries. They rented big buildings at a high price. And the primary objective was not met. [...] The NGO brought seeds and just told the population what they want. But if they were local seeds, that could have brought better results. (SOC8, 6 March 2019)

When people contacted aid organizations, they were asked to fill out forms but then did not receive any follow-up communication. Community members wanted these organizations to come to them to ask what their needs were before distributing aid.

From the interviews we conducted, it could be concluded that many community members saw the aid actors as distant, unresponsive and corrupt. Further, given people's perception that the state was appropriating aid on different levels, as described above, international organizations became complicit in the perpetuation of the society-state divide in Haiti.

This more 'extractive' nature that the aid actors were accused of in our interviews was also voiced by Haitian aid organizations as a barrier to co-shape the response. Many Haitian organizations were the implementing partners of these international aid actors, but such partnerships were not on equal terms. Some Haitian NGOs that had worked with international aid organizations before the hurricane were quickly mobilized, as recounted by an NGO staff member working with a large donor agency (NGO2, 4 April 2019). However, even when there were strong pre-existing relationships, Haitian NGOs did not enjoy the same benefits of aid funding, compared with international aid organizations. A debilitating complaint voiced by NGO staff members involved the exclusion of overhead costs from project budgets. Working as implementing partners, NGOs were unable to continue to pay their staff members' salaries and had to pay for logistics costs themselves (NGO2, 4 April 2019; NGO3, 10 May 2019). The NGOs experienced this situation as unsustainable, but they also did not feel that they had the space to negotiate other terms with their international partners.

Although societal actors did not think that they could influence communal-level state actors, these state actors themselves did feel that the people had power over them because being seen as failing to act their constituents' behalf could negatively affect these state actors' political position. State officials at the mayor's offices in Jérémie and Les Cayes noted that INGOs informed the mayor's office of their presence but that this was done only in terms of sharing information on the type and organization of the response; the INGOs had already received permission at the national level.

The limited space communal-level state actors had to negotiate the terms of the response coming from aid organizations put them in a difficult position. There was little room to negotiate the terms if these projects were badly executed (GOV4, 4 March 2019; GOV5, 5 March 2019; GOV9, 24 April 2019). One example of this mentioned by multiple state actors was the distribution of rice that was considered to be spoiled and had to be thrown out. A commune official said they had no choice but to accept the programmes because if they did not accept them the people in the commune would be angry and blame the mayor for blocking aid (GOV4, 4 March 2019). They recognized that this would negatively affect their relationship with the community.

The way the power of the central state and the politicization of aid was experienced by the affected population in response to hurricane Matthew appear similar to the historical society-state tensions that place the (colonial) state above, and outside of, society. However, it is not sufficient to say that these relations are only rooted in the past. The 'coloniality of power' is reproduced in the present and interwoven in the aid response. First, Fatton's (2011) description of the emasculated state proved more complex in practice. It took on a different form, where it was mostly experienced by local state actors not believing they had the power to confront either aid agendas or central state directives. Second, it can be seen in the way aid actors are portrayed. Much like the state, they are believed to be mostly self-interested, resembling the state's politique $d u$ ventre in both the delivery of aid as in their extractive relationship with national NGOs. As Casimir and Claypool (2012) recounted, the state is 'used' rather than 'served', and this narrative of aid organization's selfinterestedness legitimized actions of affected people 'using' the aid response instead of 'serving' it.

\section{Societal actors challenging the response through different forms of resistance}

With state and aid actors keeping the sphere of influence and power vertically organized, societal actors resisted them in different ways to change certain conditions of the response. We found that actions ranged from footdragging to protests and from theft to creative transformation of aid items. The research participants made clear that survivors challenged the dominant power structures from below. However, the space to do so was limited.

Despite stark differences between the urban centres, most notably Port-au-Prince, and the rural areas, protests and resistance to the political order manifested throughout Haiti. The rural areas might have felt to be 
overpowered by the state, but they are not powerless. The findings show that societal actors were able to shape disaster response outcomes in a different way, by resisting state-aid power structures and increasing solidaritynot only through overt action in the public space but also through more covert forms or resistance.

\section{Resisting state power: reluctance and protest}

The warnings of the impending hurricane reached people a few days to a few hours before Hurricane Matthew made landfall. In some areas, people were encouraged to seek shelter in schools or churches. However, from the narratives of the research participants, it appeared that a large majority of people ignored these messages.

The security of their belongings was important, but another significant reason that so many decided to stay in their homes was that they did not believe the messages. On the one hand, this can be seen as a 'boy who cried wolf' effect, as previous warnings were not followed by such devastating consequences. On the other hand, the division and mistrust between society and the state made the population less receptive to the messages. In an interview, a DPC officer recounted how she tried to call young fishermen to the shore, but they ignored her and said, 'We don't care about you; you do a political job, not us' (GOV12, 10 March 2019), seeing her only as a politician with ulterior motives. Only when she called the police and hid in their truck did the young fishermen leave the tumultuous sea. Defiance of the state's messages was also seen later, when the state wanted people to leave the shelters and reopen the schools. In one commune, the state was only able to close the school building when people went out during the day looking for aid; they found the building closed upon their return (SOC21, 22 April 2019).

Discontent with the state's response was reflected in demands for accountability in the media, where various instances of corruption were publicly discussed. For example, a political deputy was accused of keeping aid items instead of distributing them to the community (SOC15, 23 April 2019). Some people also used the media for their own political motives, such as discrediting communal leaders of opposing political parties (GOV8, 22 April 2019). Radio broadcasts were an outlet for people to raise a critical voice regarding the power of state politicians, and many rumours about the abuse of this power were spread through this channel. However, the radio broadcasts rarely followed up on these rumours, leaving the people in the dark about the actions of their leaders.

Many state and aid actors that we spoke with saw these public expressions of discontent with the state as the result of ignorance and reluctance to listen to authorities. However, when seen in the light of the colonial history and people's resistance to the dominant powers (Casimir and Claypool 2012), these expressions can also be understood as part of a larger pattern of societal defiance of the 'self-interested' state. Because people felt powerless to address the marginalization by the state in a public manner, other forms of resistance became part of everyday life as a means of negotiating power; Scott (1985) has referred to this as 'infra-politics'. Occupying public buildings by refusing to leave the shelters can be seen as a way of pressuring the state to continue providing aid because what has been supplied has not been sufficient. Additionally, not following the instructions of the state, for example by remaining at home when advised to evacuate, puts more strain on the state's resources, including time.

Various external sparks have the potential to shift these patterns of everyday resistance to more overt expression. In the response to Hurricane Matthew, chaotic distributions resulting in deaths served as such sparks, triggering public protests. In both Dame Marie and Les Cayes, the distribution of aid items from ships caused chaos and ended with security officers killing young people in the crowds. By the time the ships arrived, people had not received any aid for weeks. In Les Cayes, a group of Scouts recounted how people saw officials and political leaders taking food to their own houses, while most people received nothing (SOC11, 24 April 2019). Another resident described a protest by community leaders when food did not reach them after food trucks were seen coming and going, despite the mayor's responsibility to distribute this aid (SOC17, 23 April 2019). A fisherman reported that the local children formed a chain in the water, linking hands, to try to reach the ship and find aid for themselves; when the police tried to stop this behaviour, the children attempted to get away, and one teenage boy was shot and killed (SOC21, 22 April 2019). Afterwards, people blocked roads, set tires on fire and took the body of the boy into the street to show to the mayor, paralyzing the city. Although the family were compensated, the results of the investigation of this incident were not publicly announced. A week before the abovementioned protest in Les Cayes, a similar incident took place in Dame Marie. Ships tried to reach the remote commune, but the dock had been destroyed by the hurricane. Some aid was transferred from the ships to land by helicopter, and other items were transported on small private boats. When the crowd arrived to receive items from these small boats, chaos erupted; a young woman was fatally shot, and five others were injured. At the time of the fieldwork, people were still unsure about whether it was a police officer or an MINUSTAH (The United Nations Stabilization Mission in Haiti) officer who fired the fatal 
shot, as a long investigation had failed to yield conclusive results. People took to the streets to protest and demand justice for the young woman who was killed. Their anger was further fuelled by rumours that the mayor had asked for aid items from this distribution to be brought to him while children were left hungry (FG2, 8 March 2019).

In both protests, people saw the distribution of aid from the ships as poorly organized, which resulted in the challenges encountered when unloading the aid items. People in Dame Marie and Les Cayes were not informed about these aid distributions; rather, they saw the ships close to the shore-in the case of Les Cayes, for 3 days. Although this aid came from neighbouring countries and aid organizations, the people's demands for justice regarding the violent consequences were directed towards state officials in both cases. People felt that the state had to be held responsible, and resistance in the form of protests was a way for the people to exert their power over the state and a further expression of society-state disarticulation that negatively impacted the response.

\section{Shifting power over aid: increasing access by re- appropriation}

In relation to aid actors' power to determine the response to Hurricane Matthew, societal and local state actors renegotiated outcomes differently. At the level of the communes and communal sections, authorities felt that they were not included in the aid response decisions, and, according to many research participants, these authorities consequently appropriated aid for their own use. Both societal and local state participants in this research argued that aid organizations should come directly to the communities first to identify their actual needs and that they should be transparent and fair in how they distribute aid. Organizations that included community members in their distributions and that organized these distributions publicly, for example, were often well received. However, as the need was too great for the available support to address and the distribution of the aid through communal authorities was perceived as unfair, people tried to increase their access to aid in various ways. One way of doing this was by increasing pressure on the staff of aid organizations. For example, in Les Cayes, aid responders recounted moments when they felt that the affected people's anger regarding the slow and inadequate response was directed at them. One aid worker noted that, one evening, people went to random houses, knocking on the doors and making noise as a way of pressuring aid actors to help them (INGO1, 21 April 2019).

Another way of attempting to change the conditions of aid included the illegal act of stealing relief items. The research participants felt that people selectively targeted certain entities for these robberies. Both community members and aid agency representatives asserted that trucks from aid organizations were particular targets for theft. Other trucks carrying much-needed food and construction items, such as those owned by stores or other businesses, were often left alone. Haitian organizations and individuals carrying aid items to the affected regions did not report experiencing these security threats, and most community members did not feel that the security situation had changed after Hurricane Matthew.

Instances of theft also occurred around aid distributions. For example, the people on the small private boats unloading relief items from ships sometimes took these items for themselves instead of delivering them to the people waiting on the shore, and physically stronger people in distribution queues would sometimes take aid items away from more vulnerable community members. The disorganization of aid distributions was seen by the research participants as the major cause of these kinds of thefts. Unequal or insufficient distributions also caused intra-societal tension, as was seen in a communal section near Dame Marie where a limited number of bags of rice were distributed. A community member recounted how they received 10 bags of rice, which was not enough to share with the four other neighbouring localities, resulting in people from one of the neighbouring sections coming, armed with machetes, to threaten them. In response, the people of this section promised to share the items next time. This community member noted that 'if there is no food, then the fighting stops' (GI2, 7 March 2019).

In contrast to the 'everyday resistance' transforming into public displays directed towards the state, resistance to the conditionalities of aid was largely observed at the personal level. To increase individual access to relief items or to make these items more appropriate to their needs, people bent the rules. Some people described how they made sure they received food during the distributions: One woman put clothes underneath her shirt and pretended to be pregnant and was given rice and beans by the police. Another woman pretended to have a heat stroke after standing in the sun and 'fainted' to receive relief items. A young man behaved as though he had a mental disability to get food. This sort of deception was a tool for people to use the system in a way that worked better to address their needs.

A common complaint among the research participants was that the aid provided was not appropriate for their needs. Therefore, the re-appropriation of relief items, through exchanging these items for other items or selling them for cash, for example, was used as a way for people to receive the support they needed. For instance, the distributed tarps were 
sometimes resold for 'pocket money' (FG3, 7 March 2019), and vouchers or cards for seeds that might be exchanged for cash (FG1, 6 March 2019; INGO5, 10 April 2019; NGO8, 24 April 2019).

\section{Solidarity: alternative resistance within the system}

Given that aid-society relations were disadvantaged by the insufficiency in available aid to meet the needs of the affected communities, and, simultaneously, society-state relations were tense, social networks were especially crucial for people after Hurricane Matthew. As Schuller (2016) has pointed out, community associations are flexible in nature but have often been overlooked by INGOs. In the present study, such associations were described as useful by many people. A religious leader commented, 'Between the rice, little stones taste fat' (SOC13, 23 April 2019), describing a beneficial side effect in a difficult situation where also the neighbours benefitted from the support that affected people received. Solidarity groups were seen by the community members as positive forces in their communities, in contrast to aid organizations, which were often seen as obstacles to overcome.

'Tout moun se moun, men tout moun pa menm' is a common Haitian Creole proverb that translates as 'Every person is a person, but not all persons are the same'. This saying reflects both strong solidarity and the substantial inequality based on racial and class divisions among people in Haiti. Despite the significant inequality between the (political) elite and others, Haitian communities have strong solidarity networks to provide mutual assistance in response to the absent state, particularly in rural areas. Although the state has marginalized those living outside of Port-au-Prince, a counter-narrative has been built on the need to be self-reliant and to 'use' the state without being a part of it. Because societal actors could not rely on the state for support, people sought to carve out larger societal spaces in response to Hurricane Matthew as a way to shape the conditions of aid.

\section{Community-based aid structures}

In the disaster-affected communities, people relied on many solidarity structures that operate as the foundation of everyday solidarity and are strengthened in times of crisis. The members of VSLAs (Village Savings and Loans Associations) and cooperatives, in particular, were able to rely on these kinds of networks. Moreover, traditional practices such as the Konbit (where a group of people come together to work for a community project) brought people together, and family connections-both within Haiti and beyond-were vital in the disaster response.

VSLA groups are important solidarity groups in Haitian communities. These groups were often initially set up by development programmes to encourage community-based micro-loans and support. After Hurricane Matthew, VSLA group members found that such support 'helped to survive' (FG3, 7 March 2019). These people had nothing after the hurricane, and the VSLA provided them with the opportunity to access funds (FG2, 8 March 2019). The 'strength of the group is the group itself' (FG3, 7 March 2019); even with very little means, they were able to put money together to help each other, although some of these groups struggled. As everyone was affected by the disaster, the groups needed to prioritize the allocation of support. To accomplish this, they analysed individual cases and attempted to serve the most vulnerable first (FG2, 8 March 2019). Groups with ties to aid organizations were able to access additional money from these organizations; they then set up loans for their members to assist them with commerce, gardens and school fees (FG1, 6 March 2019). Different organizations have come into the area, but only the VSLAs have remained (FG3, 7 March 2019).

Cooperatives were another powerful network node. Such organizations often had pre-established relationships with external donors, and they were able to use these connections to increase their access to aid. Cooperative members often benefited from aid kits and also supported each other during the recovery period. In an interview, a Cacao Cooperative member explained that the cooperative helped with providing the first necessities for their members, which numbered over 600, with the help of their donor partners. Cooperatives also encouraged members to replant their gardens so that they would later provide sustenance (SOC8, 6 March 2019). Therefore, the cooperatives were helpful not only in the short term but also for medium- and long-term recovery.

Regarding social structures, the Konbit, family and diaspora were important foundations of the response. In conversations about aid actors, community members would often say that aid 'killed the Konbit'. According to these research participants, because aid agencies offered local people cash payments for work, people engaged less in the traditional Konbit, in which residents performed community work. After Hurricane Matthew, some affected communities were initially cut off from the rest of the country. As mentioned at the start of this article, during and after any disaster, the community members in an affected area are the first responders, helping each other in many ways. As a Boy Scout asserted in an interview, 'Living here, where the government is absent, all the things they [community members] did [were done] by themselves' (SOC11, 24 April 2019). Multiple examples of such 'things' emerged in the community members' narratives about the post-disaster period: People went to find refuge in the more strongly built houses of their neighbours before and during the 
hurricane. Community members and leaders hosted displaced families. People worked together to clean up fallen trees and debris, and they cleared roads using shared tools to allow the resumption of traffic and to enable aid to reach the areas. Food was shared with neighbours, family members and friends. If someone did not receive aid, others often shared what they received.

Similarly, family members, friends and social connections in Port-au-Prince were vital for support after Hurricane Matthew. Although the aid organizations could not immediately reach remote communities, individuals were able to make their way to these locations with supplies and aid items. For example, a man living in Port-au-Prince who had not heard from his family members in a remote commune in the affected region travelled to help them by car, bringing mattresses and supplies. This man did not bring items only for his family; other people staying at the shelter housing his relatives were also helped by these items (SOC25, 4 May 2019). When asked what people had done to recover from the disaster, community members stressed this type of sharing: 'We shared and worked together. If someone else had family members in Port-au-Prince and if they sent rice, they shared the rice' (GI1, 8 March 2019).

The Haitian diaspora was another source of support after Hurricane Matthew, but the research participants were divided on how helpful the diaspora was. Diaspora organizations raised money and supported communities in Haiti. Some organizations, particularly in the USA, did so on a relatively large scale. All this help was much needed and appreciated: 'Haitians, when they are in a difficult situation, they help each other. Not in a formal way to plan to do it, but they did it', a youth representative asserted (SOC14, 8 March 2019). Before and after Hurricane Matthew, 'Haitians send aid to their families. That's what supports them' (SOC5, 5 March 2019). However, this did not always translate into direct help, and it could not always be expected: 'Even if you have [family in the diaspora], then they don't care about us. When I called my cousin in the United States, she told me, "Don't you have Jehovah? Go and pray"' (FG3, 7 March 2019).

\section{Resisting the society-aid divide: religious actors and the private sector}

With society-state tensions intensified and society-aid relations being under pressure, there was a gap to be filled. In terms of alternative sources of aid, religious institutions and the private sector were crucial for the affected communities. Churches opened their doors and supported the communities. In addition to schools, churches were used as shelters, both during and after the hurricane. However, many church buildings were also greatly affected themselves, with their roofs not being able to withstand the force of the hurricane, as community member explained: 'Yes, they helped. But they also couldn't do anything because the church was also destroyed' (GI1, 8 March 2019). Additionally, churches and their leaders served as connectors-mediators between the communities and aid actors-and were included in aid projects by many aid organizations because church networks were seen as knowing the communities well. As one INGO representative stated, 'They [pastors] have the ability to mobilize people' (INGO1, 21 April 2019). The churches that were used as shelters also provided meals for community members. Religious leaders, in turn, tried to mobilize support in the cities, and churches received support from associated (mother and sister) churches in Port-au-Prince and other places that were not affected by Hurricane Matthew, as well as from the Haitian diaspora. For example, one church used international charity funding to rebuild houses for their members, and another fundraised with their sister churches in other Haitian cities (SOC12, 24 April 2019; SOC20, 21 April 2019). Especially in Les Cayes, the presence of many churches aided the response for church members and neighbours. However, not all churches were well organized or wanted to coordinate with other churches: 'In Catholic churches yes, but not Protestant ones. There was no coordination there' (IO1, 15 May 2019). Furthermore, the power of religious leaders to increase people's access to aid varied between local churches and the international churches with a strong presence in Haiti.

The role of international religious actors can be seen as an extension of aid, especially US-based aid. International churches were also able to connect people with essential funding, serving as an alternative to the state and aid actors, which were viewed with mistrust. An international organization representative described people's trust of churches as follows: 'They respect churches. They are well known and trustworthy, working for the community's well-being. None of those assumptions exist with international actors' (IO2, 16 May 2019). After Hurricane Matthew, international churches with a strong presence in the country were able to quickly mobilize resources through their charities, assess the situation and respond, mostly in areas where they had already been operating. These international churches collaborated with Haitian churches and were strongly rooted in the communities. An international church leader asserted, 'We had communities totally engaged with us' (IO2, 16 May 2019). Additionally, the churches planted by international movements were able to quickly obtain international funding and provide aid-not only for their members but also for others living in the area. Furthermore, a group of Protestant churches organized as an alliance. Overall, these church 
networks operated mostly in parallel to the aid organizations and in collaboration with the US and with Haitian state structures. Although it could be argued that these international churches are part of the neocolonial power structures, they also experienced the domination of aid agencies, which were not always willing to connect with church networks. This negatively impacted the church networks' attempts to collaborate with aid organizations.

Many private businesses also responded to Hurricane Matthew, either through an alliance or individually. Alliances of companies were involved in official aid mechanisms, but businesses operating individually worked outside these mechanisms and chose to resist coordination efforts. The private sector is important for disaster response in all contexts, both in their role as contractors and though corporate foundations. In this research, it became clear that businesses in the affected region were also able to capitalize on the response through initiatives such as hardware stores supplying kits purchased by a business participating in the response (SOC10, 24 April 2019), seed distributors selling seeds to an INGO (INGO5, 10 April 2019) or a small mattress shop selling a large quantity of mattresses at reduced prices and making a profit (SOC18, 20 April 2019)-albeit on a small scale. These examples also illustrate international aid organizations acting on their intention to source goods locally and prevent the 2010 earthquake response's 'disaster capitalism' (Klein 2008; Dupuy 2010) that negatively impacted the Haitian private sector.

Some other businesses with international partners were able to mobilize resources quickly because of the trust their international partners already had in them. As one private sector employer recounted, 'People sent money because they are in business with us, so they could trust us. Many times they hear stories that aid is not reaching the beneficiaries to pay for the salaries and housing of the staff. So people didn't want to give to the Red Cross or INGOs, but rather to help local people directly' (SOC10, 24 April 2019). Another person working in the private sector reiterated this point: 'Maybe people trust us more. People are wary about INGOs after the earthquake. We make things available right away, whereas INGO would be bothered by bureaucracy behind it because they work with government agencies' (SOC1, 14 May 2019). By finding their own way and operating outside the aid structure, businesses were less often targeted by people blocking trucks and stealing aid items. Although private businesses mostly limited their support to their employees, other people in the communities also benefited from aid distributions.

\section{Conclusion}

In disaster response governance, societal actors are the first responders. However, as humanitarian practice has shown, their role remains limited in terms of deciding how the response is organized. Previous work has focused on aid-society relations as a limiting factor; the present study argues that this is especially problematic in a context where there is strong state-society disarticulation. Viewing crises as catalysts for change that allow structural tensions to be overcome implies that the inevitable result will be increased societal engagement in disaster governance. Our research findings suggest that the situation is more complex than this.

Instead of serving as a 'tipping point' for change, Hurricane Matthew intensified society-state relations through everyday politics. Societal actors in Haiti faced challenges in negotiating power relations in disaster governance because of the strong politicization of aid that strengthened people's lived experience of the 'politique $d u$ ventre', which served to fill the bellies of elites and partisans, sometimes quite literally. Internalized discourses of colonialism and crisis shaped how different response actors defined their relationships. The perceived self-serving nature of aid contributed to further eroding society-state-aid relations and to limiting the space for societal actors to take a larger role in disaster governance.

The society-state disarticulation strongly impacted people, reducing their trust in the state across all phases of disaster governance. Many state and aid actors saw societal actors' lack of trust and consequent behaviours as ignorance and reluctance to follow instructions on the part of societal actors. However, this reaction among the people follows a larger pattern of societal defiance of the state and the international system seen in Haiti and beyond. Acts of resistance observed included public protests seeking to hold the state accountable and demonstrate the people's power over the state.

Re-appropriation strategies were another form of resistance. When people lack information on aid support but see aid items pass them by although they are in need, or when people must accept the type of aid and method of distribution dictated by external aid actors, power is imposed. People demonstrated their concerns through their actions in a context where space for negotiating the response was limited. These actions in response to Hurricane Matthew contested the structural society-state-aid power relations.

Societal actors needed to carve out their own space in the social realm. Outside of traditional state-aid structures, disaster response took different forms, and solidarity was mostly found in the support offered by religious actors, private sector institutions, and community-based associations. Here, solidarity can be seen as part of the resistance to the dominant state and aid structures-a 
counter-narrative in which societal actors define the conditions of aid on their own terms.

This study also adds to the understanding of changes in disaster response policies and practices more generally, where the desired localization of humanitarian aid faces challenges in practice. Our findings show that the extent to which power and politics are centralized in a given context is an important factor to consider when exploring the space different actors have to negotiate the outcomes of aid. Therefore, to achieve a more locally led disaster response, structural relations between society and the state should be addressed, and alternative aid structures supported.

\section{Abbreviations}

CASEC: Conseils d'Administration de Section Communale; DPC: Direction de la Protection Civile; INGO: International Non-Governmental Organization; IO: International Organization; NGO: Non-Governmental Organization; VSLA: Village Savings and Loans Association

\section{Acknowledgements}

Not applicable.

\section{Authors' contributions}

SM has designed the research, collected and analysed the data and wrote the manuscript. MJ facilitated a large part of the data collection, supported the initial analysis of the data and contributed to the improvement of the manuscript. All authors have read and approved the final manuscript.

\section{Funding}

This paper was made possible by a $\mathrm{VICl}$ grant from the Netherlands Organisation for Scientific Research (NWO; Grant number: 453-14-01).

\section{Availability of data and materials}

The dataset generated and analysed during this study are not publicly available due to privacy and protection concerns of the research participants.

\section{Competing interests}

The authors declare that they have no competing interests.

\section{Author details}

${ }^{1}$ International Institute of Social Studies, Erasmus University Rotterdam, Kortenaerkade 12, 2546 BK The Hague, The Netherlands. 'Université Episcopale d'Haïti, 14 Rue Légitime Champs-de-Mars, Port-au-Prince, Haiti.

Received: 3 August 2020 Accepted: 10 January 2021

Published online: 25 January 2021

\section{References}

Artur L (2011) Continuities in crisis: everyday practices of disaster response and climate change adaptation in Mozambique. s.n., Netherlands

Bakewell O (2000) Uncovering Local perspectives on humanitarian assistance and its outcomes. Disasters 24:103-116 https://doi.org/10.1111/1467-7717.00136

Bankoff G (2003) Cultures of disaster: society and natural hazards in the Philippines. Routledge, Curzon, London; New York

Barnett MN (2011) Empire of humanity: a history of humanitarianism, Cornell paperbacks, 1. print. Cornell Univ. Press, Ithaca, NY

Barnett MN (2013) Humanitarian governance. Annu Rev Polit Sci 16:379-398 https://doi.org/10.1146/annurev-polisci-012512-083711

Berger PL, Luckmann T, Zifonun D (2002) The social construction of reality. na

Bhattacharjee A, Lossio R (2011) Evaluation of OCHA response to the Haiti earthquake. Final Rep January

Braun V, Clarke V (2006) Using thematic analysis in psychology. Qual Res Psychol 3:77-101 https://doi.org/10.1191/1478088706qp063oa

Casimir, Claypool (2012) Going Backwards Toward the Future: From Haiti to Saint-Domingue. Glob South 6:172 https://doi.org/10.2979/ globalsouth.6.1.172
Casimir, Colon, Koerner (2011) Haiti's Need for a Great South. Glob South 5:14 https://doi.org/10.2979/globalsouth.5.1.14

Césaire A (2000) Discourse on colonialism. Monthly Review Press, New York Cunningham AJ (2018) International humanitarian NGOs and state relations: politics, principles, and identity. Routledge, Abingdon, Oxon ; New York, NY

Donais T, Knorr AC (2013) Peacebuilding from below vs. the liberal peace: the case of Haiti. Can J Dev Stud Can Détudes Dév 34:54-69 https://doi.org/10. 1080/02255189.2013.761130

Donini A (ed) (2012) The golden fleece: manipulation and independence in humanitarian action, 1st edn. Kumarian Press, Sterling, Virginia

Dubois L (2013) Haiti: the aftershocks of history, First Picador edition. Picador, New York

Dupuy A (2010) Disaster capitalism to the rescue: the international community and Haiti after the earthquake. NACLA Rep Am 43:14-19 https://doi.org/10. 1080/10714839.2010.11722192

Fanon F (2002) The wretched of the earth. Grove, New York

Farmer P (2012) Haiti after the earthquake. PublicAffairs, New York

Fast $L$ (2017) Upending humanitarianism: questions emerging "from the ground up"

Fatton R (2002) Haiti's predatory republic: the unending transition to democracy. Lynne Rienner Publishers, Boulder, Co

Fatton R (2011) Haiti in the Aftermath of the Earthquake: The Politics of Catastrophe. J Black Stud 42:158-185 https://doi.org/10.1177/ 0021934710396369

Foucault M (1984) The order of discourse. In: Shapiro MJ (ed) Language and Politics. New York University Press, New York

Geoffroy V, Grünewald F (2017) More than the money-localization in practice

Giddens A (1984) The constitution of society: outline of the theory of structuration. Univ of California Press, Oakland, CA

Glaser BG, Strauss AL (1967) The discovery of grounded theory: strategies for qualitative research. Aldine Pub. Co., Chicago

Grünewald F, Schenkenberg E (2017) Real time evaluation: response to hurricane Matthew in Haiti

Gurr TR (1970) Why men rebel. Published for the Center of International Studies, Princeton University [by] Princeton University Press, Princeton, N.J

Hayward CR (2000) De-facing power. Cambridge University Press, Cambridge, UK New York

Hilhorst D (ed) (2013) Disaster, conflict and society in crises: everyday politics of crisis response. Routledge, New York

Hilhorst D (2016) Aid-society relations in humanitarian crises and recovery. Institute of Social Studies of Erasmus University Rotterdam, The Hague, The Netherlands

Hilhorst D (2018) Classical humanitarianism and resilience humanitarianism: making sense of two brands of humanitarian action. J Int Humanit Action 3: 15 https://doi.org/10.1186/s41018-018-0043-6

Hilhorst D, Jansen B (2010) Humanitarian space as arena: A perspective on the everyday politics of aid. Dev Change 41:1117-1139

Hsu KJ, Schuller M (2019) Humanitarian aid and local power structures: lessons from Haiti's "Shadow Disaster." Disasters disa.12380. https://doi.org/10.1111/disa.12380

Jean-Louis D, Klamer J (2016) From aid to trade: how aid organizations, businesses, and governments can work together: lessons learned from Haiti. Fresh Strategy Press, Grand Rapids, Michigan

Jenson D (2011) The writing of disaster in Haiti: signifying cataclysm from slave revolution to earth quake. In: Munro M (ed) Haiti Rising: Haitian History, Culture and the Earthquake of 2010. University of the West Indies Press, Mona, Kingston, Jamaica, pp 103-112

Klein N (2008) The shock doctrine: the rise of disaster capitalism. Picador, New York

Krüger F, Bankoff G, Cannon T et al (eds) (2015) Cultures and disasters: understanding cultural framings in disaster risk reduction, 1 Edition. Routledge, Taylor \& Francis Group, London, New York

Lewis J (2012) The good, the bad and the ugly: disaster risk reduction (DRR) versus disaster risk creation (DRC). PLoS Curr 4:e4f8d4eaec6af8 https://doi. org/10.1371/4f8d4eaec6af8

Lukes S (2004) Power: a radical view, 2nd ed. Palgrave Macmillan, Houndmills, Basingstoke, Hampshire : New York

Lundahl M (1989) History as an obstacle to change: the case of Haiti. J Interam Stud World Aff 31:1-22 https://doi.org/10.2307/165908

Maldonado-Torres N, Cavooris R (2017) The decolonial turn. In: Poblete J (ed) New Approaches to Latin American Studies: Culture and Power, 1st edn, vol 2018. Routledge, New York, NY 
Mason CL (2011) Foreign aid as gift: the Canadian broadcasting corporation's response to the Haitian earthquake. Crit Stud Media Commun 28:94-112 https://doi.org/10.1080/15295036.2011.559479

McAdam D (1982) Political process and the development of Black insurgency, 1930-1970. University of Chicago Press, Chicago

Melis S, Hilhorst D (2020) When the mountain broke: disaster governance in Sierra Leone. Disaster Prev Manag Int J ahead-of-print: https://doi.org/10. 1108/DPM-03-2020-0076

Migdal JS (2001) State in society: studying how states and societies transform and constitute one another. Cambridge University Press, Cambridge ; New York

Mignolo W, Walsh CE (2018) On decoloniality: concepts, analytics, praxis. Duke University Press, Durham

Mignolo WD, Escobar A (eds) (2010) Globalization and the decolonial option, 1. publ. Routledge, London New York

OCHA (2016) Haiti: Hurricane Matthew-situation report No. 19 (2 November 2016)

Pelling M, Dill K (2010) Disaster politics: tipping points for change in the adaptation of sociopolitical regimes. Prog Hum Geogr 34:21-37 https://doi. org/10.1177/0309132509105004

Quijano A (2000) Coloniality of power and eurocentrism in Latin America. Int Sociol 15:215-232 https://doi.org/10.1177/0268580900015002005

Rencoret N, Stoddard A, Haver K, et al (2010) Haiti Earthquake response: context analysis. Humanitarian Outcomes and ALNAP

Schuller M (2016) Humanitarian aftershocks in Haiti. Rutgers University Press, New Brunswick, N.J

Scott JC (1976) The moral economy of the peasant: rebellion and subsistence in southeast Asia. Yale University Press, New Haven

Scott JC (1985) Weapons of the weak: everyday forms of peasant resistance. Yale University Press, New Haven

Siddiqi A, Canuday JJP (2018) Stories from the frontlines: decolonising social contracts for disasters. Disasters 42:S215-S238 https://doi.org/10.1111/ disa. 12308

Solnit R (2010) A paradise built in hell: the extraordinary communities that arise in disaster. Penguin Books, New York

Svistova J, Pyles $L$ (2018) Production of disaster and recovery in post-earthquake Haiti: disaster industrial complex, 1st edn. Routledge, Abingdon, Oxon ; New York, NY Routledge, 2018. | Series: Routledge humanitarian studies series

Tarrow SG (1998) Power in movement: social movements and contentious politics, 2nd ed. Cambridge University Press, Cambridge [England] ; New York

The Grand Bargain (2016) The grand bargain: a shared commitment to better serve people in need. World Humanitarian Summit (WHS), Istanbul, Turkey

Tiernan A, Drennan L, Nalau J et al (2019) A review of themes in disaster resilience literature and international practice since 2012. Policy Des Pract 2: 53-74 https://doi.org/10.1080/25741292.2018.1507240

Tierney K (2012) Disaster Governance: Social, Political, and Economic Dimensions. Annu Rev Environ Resour 37:341-363 https://doi.org/10.1146/annurevenviron-020911-095618

Ulysse GA, Ménard N, Trouillot É et al (2015) Why Haiti needs new narratives =: Sa $k$ fè Ayiti bezwen istwa tou nèf = Pourquoi Haïti a besoin de nouveaux discours: a post-quake chronicle. Wesleyan University Press, Middletown, Connecticut

UNISDR (2015) Sendai framework for disaster risk reduction 2015-2030. UNISDR, Geneva, Switzerland

Venugopal R, Yasir S (2017) The politics of natural disasters in protracted conflict: the 2014 flood in Kashmir. Oxf Dev Stud 45:424-442 https://doi.org/10.1080/ 13600818.2016 .1276160

Vickers E (2019) Critiquing coloniality, 'epistemic violence' and western hegemony in comparative education - the dangers of ahistoricism and positionality. Comp Educ:1-25 https://doi.org/10.1080/03050068.2019. 1665268

Wisner B (2016) Vulnerability as concept, model, metric, and tool. In: Oxford Research Encyclopedia of Natural Hazard Science. Oxford University Press, Oxford [England]

\section{Publisher's Note}

Springer Nature remains neutral with regard to jurisdictional claims in published maps and institutional affiliations.

\section{Submit your manuscript to a SpringerOpen ${ }^{\circ}$ journal and benefit from:}

- Convenient online submission

- Rigorous peer review

- Open access: articles freely available online

High visibility within the field

- Retaining the copyright to your article

Submit your next manuscript at $\boldsymbol{\nabla}$ springeropen.com 